\title{
CONSTITUIÇÃO, SOBERANIA E MERCOSUL
}

\section{CÁRMen lúcia Antunes Rocha*}

"Vapor Barato, um mero serviçal do narcotráfico Foi encontrado na ruína de uma escola em construçāo Aqui tudo parece que é ainda construção e já é ruína Tudo é menino e menina no olho da rua $O$ asfalto, a ponte, o viaduto ganindo para a lua Nada continua Eu não espero pelo dia em que todos os homens concordem Apenas sei de diversas harmonias bonitas possiveis Sem juizo final

Alguma coisa está fora da ordem Fora da nova ordem mundial."

- Fora da Ordem Caetano Veloso

Introduçāo. I - O constitucionalismo contemporâneo: sentido e funções da Constituição. II - Constituição e direito supranacional. III - Constituição e Soberania no Direito Brasileiro. IV - A Constituição da República Brasileira e o Mercosul. Conclusão.

\section{Introdução}

O homem multiplica-se. Em sua versão individual, em sua versão social, em sua aspiração política. em sua conspiração voltada ao geral, em seu eterno tornar-se. Democratiza-se o homem; diversifica-se ele, amplia-se.

* Advogada

R. Dir. Adm., Rio de Janeiro, 213: 35-65. jul./set. 1998 
Não é que antes o homem não se modificasse sempre. É que agora as mudanças fazem-se como turbilhão incessante. Não há tempo para se adquirir o hábito das coisas ou das instituições. O que antes era novo já se fez velho antes mesmo de ser conhecido. E é, então, descartado. O próprio homem parece ver-se alvo de comportamentos, especialmente no espaço dos escambos mercantis, que o tratam, em grande parte, como algo descartável, suprimível, ou pelo menos facilmente substituível.

As criações humanas proliferam, desfazem-se, liquefazem-se.

Antes, e durante séculos, houve um modelo de organização religiosa, projetada pela Igreja, a qual, conquanto não única nos diversos grupos humanos, adotava um mesmo formato, o mesmo paradigma de regras a fundamentar-lhe a estruturação. Mesmo quando novas Igrejas eram instituídas - a protestante ou a anglicana, para citar dois exemplos - o modelo inicial perseverava.

Todavia, a Igreja não foi capaz de superar a incrível distância entre os seus postulados, dogmas e pompas e as indagações dos homens que lhes seguiam os mandamentos. O reino da terra faz-se cada vez mais próximo e doído e requer respostas. $\mathrm{O}$ reino dos céus faz-se cada vez mais distante e os seus resultados não se mostram. O homem busca, então, novos caminhos, atalhos que satisfaçam, mais proximamente, ou pelo menos lhe dêem a ilusão de saciarem-se suas fomes, suas paixões, consolo ou ouvidos para as suas lágrimas e lamentações, que sempre há do que se lamentar na vida. O homem procura espaço para ensaiar o salto que lhe acode transpor a cada instante. Daí a multiplicação de igrejas. A que vêm, o que trazem são questões que não se há deixar de considerar. Mas, de pronto, pode-se atestar que as novas e múltiplas igrejas, com seus formatos, nomes e propostas variados carreiam multidões em todos os lugares do mundo. Nem se há negar o poder que estas multidões, organizadas, sincronizadas em sua ação por um vínculo que os une, ostentam e fazem valer. A diferença destas novas organizações havidas como religiosas e o que antes se tinha é o modelo e os fundamentos havidos em relação à Igreja tradicional. Esta ensimesmou-se, fechou-se e negou-se a ver que o povo conduz-se sem os parâmetros que lhe são firmados de fora no momento mesmo em que estes não os contentam. Não há cabresto histórico que mantenha a cabeça de um povo num lugar que se lhe predetermine. Não há mordaça que o faça sem voz quando o impulso de gritar o acolhe. O ecumenismo impõe-se, as Igrejas convivem, os fiéis e não fiéis, crentes, descrentes ou ateus organizam-se segundo as suas conveniências momentâneas ou eternas, fugazes ou permanentes.

Não é muito diferente e nem parece ter base diversa o fenômeno que ocorre com o Estado. Reproduzem-se as organizações sociais ao lado do Estado, dentro do Estado, supra ou transnacionalmente. O poder político, antes soberanamente havido como exclusivo do Estado, atomiza-se, socializa-se. O Estado que se acreditara e se ensimesmara como essencial por si mesmo vê-se apenas mais uma proposta, dentre tantas, de forma de regulação do poder dos homens em sua experiência social.

Os elementos que, tradicionalmente, eram tidos como essenciais ao Estado povo, território e poder soberano - fazem-se cada vez mais distintos em sua concepção e acolhimento teórico e prático.

O povo, constitucionalmente conceituado e ao qual se garantem direitos e se impõem deveres, dota-se de novas definições (povo substancial, por exemplo), de 
novos direitos ao lado e acima do Estado (direito de resistência às leis injustas, por exemplo) e de novas formas de organização (organizações não governamentais, por exemplo).

O território faz-se cada vez mais virtual, para se usar de uma expressão corriqueira da atualidade. Fronteiras são menos valorizadas em sua contingência física. As liberdades de pessoas, bens, capitais e serviços não se põem nem se afirmam nos limites territoriais. Mais e mais a tecnologia (especialmente as telecomunicações e a teleinformática) desconhecem limites, fronteiras ou sequer noção de território. Nem o planeta é mais considerado limite, que dirá uma parte da terra... Aqueles que se perguntavam sobre o "terceiro mundo" - e que já não eram tantos — hoje vêem-se às voltas com as indagações sobre o "quinto mundo", que é o dos refugiados e dos emigrantes acolhidos por Estados nos quais eles se mantêm com os seus mesmos costumes, regras e comportamentos. Entretanto, a pessoa estatal que os recebe tem o seu próprio direito positivo, conquanto a admissão faça-se gesto de boa vontade com a multicultura e o multiregramento social. Os direitos humanos não têm fronteiras. Sendo certo que os crimes também as desconhecem. As drogas firmam as suas trilhas multinacionalmente, a corrupção é transnacional, o terrorismo é internacional. Logo, o direito tem que fazer face a estas novas contingências, que nada têm de territoriais e fronteiriças.

$O$ poder estatal que se qualificava e se distinguia dos demais como soberano faz-se sempre mais socializado, repartido, reconfigurado segundo novos paradigmas ditados pelas novas organizações formadas e informadas pelas demandas políticas dos indivíduos agregados em entidades que se fazem atores políticos ativos e permanentes. O pluralismo político demonstra-se no plano interno e no plano externo. Em razão deste princípio tem-se, de uma parte, a possibilidade de serem admitidas opções políticas diferenciadas e coexistentes e, de outra, a participação de organizações variadas dotarem-se de poderes e dinamizarem-se como atores partícipes do processo político.

Neste quadro, o Estado - tal como se dá com a Igreja tradicional e sobranceira — já não é um modelo único e tido ou aceito como "o mais perfeito" de organização política, nem talvez o soberano, pelo menos se pensarmos esta palavra com o mesmo e idêntico conteúdo com que o premiou Jean Bodin. O povo, tido como titular do poder político, retoma, agora mais diretamente, o exercício do poder soberano, fazendo-se presente e permanente no processo de realização de seus interesses.

Mais importante ainda é que a organização política da sociedade em grupos estruturados e formalizados segundo normas jurídicas dotadas de eficácia afirma-se, não poucas vezes, como uniões multinacionais. Os homens encontram-se, reúnem-se, associam-se para a obtenção de seus objetivos comuns e que não se limitam a fronteiras. Especialmente na matéria que concerne à essência do ser humano, aos direitos fundamentais, aos deveres com o meio ambiente, ao respeito aos princípios democráticos, dentre outros, a convergência dos interesses e fins buscados em todos os quadrantes do planeta orientam e direcionam o homem em grandes encontros.

Nas duas últimas décadas emerge e vira moda o fenômeno rotulado de globalização. No fluxo do processo que se firma sobre as bases de necessidades de mercados e de mais consumidores para a produção empresarial voltada ao lucro empresarial mais que à necessidade social se afinam interesses que discursam sobre 
novas práticas políticas ou feitas em nome da política. No fluxo do processo, aliás, abrem-se tanto possibilidades de uniões humanas e humanitárias quanto riscos de exclusões desumanas e segregadoras e até mesmo de novos quadros de apartheid social. O colonialismo veste-se com a indumentária daquele discurso globalizante. Mas é certo que os direitos humanos forçam o seu reconhecimento e prática mundiais. A experiência agressiva da civilização do ter sugere o aparecimento de vozes ponderando pela vivência do ser. Contra a modernidade do ganho (donde vem a ganância) a eternidade do benefício humano (donde vem a solidariedade). A tendência associacionista internacional pode se converter num veio promissor de novas possibilidades de uniões entre os povos ou, conforme a senda pela qual se decidirem as comunidades, numa anulação de identidades culturais, históricas e diferenciadoras para a garantia do ser humano livre e único em sua condição pessoal.

Neste quadro de tantas aventuras e desventuras velhas e novas, inéditas e repetidas, alvissareiras e ameaçadoras, o Direito faz-se objeto de mudanças radicais. Mais que qualquer outro, é o Direito Constitucional que sente e se ressente primeiramente destas mudanças, pela circunstância mesma de ser a raiz donde brotam os demais ramos que integram o ordenamento jurídico.

A Constituição faz-se outra que não apenas aquela pensada nos últimos dois séculos. Mas continua a ser necessária por ser uma garantia do homem sedimentada no Direito e na convivência política democrática. Qual é a sua essência ou a sua matéria é questão mutante, mais discutível agora, pelo que é ainda difícil vislumbrar-se ela em sua inteira justeza. Só é certo que seja ela qual for não se dá a sonegar o homem. sua alma mais composta e certa; não se lhe busca desatender os fins para ceder preferencialmente a um fácil deus manon. É certo que se alteram as suas funções e as suas feições. Para ter a cara do povo a que se dá a ser. Figurar-se sua nova fisionomia é o desafio. É tempo de reinventar o processo civilizatório e, em seu fluxo, reinventar o jurídico. Talvez seja o tempo mais propício de nos redescobrirmos, de nos ganharmos com os quinhentos anos de história de tantas perdas sul americanas, de nos fazermos com os ideais da pátria grande dos tantos que não conseguiram antes negar ou impedir a desconstrução nas quais nos contiveram. Vislumbra-se, de par com as dificuldades, as possibilidades que se oferecem ao estudioso do Direito e ao cidadão que vivem esta nova revolução no planeta: a que pretende alcançar a cidadania digna. humanamente digna, a se fazer de todos e para todos os homens e não apenas de e para pequenos grupos; aquela que se dá a ser um momento no qual se pode propor a ser melhor para um mundo mais perfeito para a universalidade dos homens. Se há uma crise do Direito (ou no Direito) é que há uma crise dos sonhos do homem. Tanto melhor se é preciso tanto para se viver ainda esta certeza: a de que ele continua a sonhar e a fazer de suas utopias suas estrelas guias.

\section{I - O constitucionalismo contemporâneo: sentido e funções da Constituição}

" $L$ 'actualité déforme les problèmes, parce qu'elle n'en retient qu'un aspect fugitif; elle les dramatise et, par conséquent, les écarte de la perspective scientifique..." 
1 - O conceito de Estado de Direito enraíza-se no de Constituição traçado modernamente. $O$ fundamento daquele repousa mesmo no conceito de Constituição, pois o movimento constitucionalismo afirmou dois princípios, a saber. o de que a liberdade (e mesmo os demais direitos posteriormente rotulados de primeira geração, como querem alguns, ou de primeira dimensão, como preferem outros) depende do seu reconhecimento e garantia firmados num sistema de direito soberanamente criado e positivado em determinada sociedade e estruturado numa hierarquia normativa rigidamente observada; e o de que para que aqueles direitos sejam invulnerados e invulneráveis é de se estruturar o poder político estatal. de tal modo que haja um sistema de funções e órgãos normativamente postos limitadores daquele exercício. Com este conteúdo é que se estabeleceu, no discurso revolucionário de 1789 , que " toute societé dans laquelle la garantie des droits n'est pas assurée ni la séparation des pouvois determinée n' a point de constitution" (art. 16, da Declaração dos Direitos do Homem e do Cidadão).

O desenvolvimento do constitucionalismo moderno de seus primórdios até a atualidade fez-se, grandemente, somente como desdobramento daquelas idéias e a sua revelação mais precisa e plural traduzida em outros princípios e preceitos que multiplicaram as instituições e os instrumentos jurídicos nos sistemas normativos. $\mathrm{O}$ direito não apenas como regulação do poder limitado, mas principalmente prestante e destinado a servir ao homem foi sendo conquistado no curso dos séculos que medem a denominada modernidade. É certo que não se obteve, do período setecentista e oitocentista até a atualidade, transformação essencial do modelo político que se apresentou e se representou no primeiro esboço do Estado de Direito, firmado, principalmente, no projeto liberal e liberalizante que prevaleceu.

$\mathrm{Na}$ base desta concepção do constitucionalismo firmou-se o princípio da supremacia da Constituição, e, por força de tal idéia e mesmo dos ideais de justiça que nela se contém, cunharam-se instrumentos que assegurassem a sua eficácia, tais como o do controle da constitucionalidade das leis e o da reforma específica da Constituição dotada de rigidez formal. Essas duas vias assecuratórias do princípio da supremacia da Lei Fundamental não se fez como mera codificação de normas jurídicas, mas como meio de se formalizar a garantia de eficácia dos direitos nela reconhecidos e a eficiência das funções estatais para a realização dos fins havidos como próprios no sistema, quer pela descrição do poder constituinte, quer pela interpretação dos poderes constituídos dotados de tal competência.

2 - Foi neste século XX e, basicamente, com o surgimento do que se apelidou de "constitucionalismo social" que se teve a introdução da referência ao Estado Constitucional, o qual se adicionou à menção feita ao Estado de Direito. A República de Weimar contribuiu para o assentamento daquela expressão e foi nela que se sedimentou o controle da constitucionalidade das leis como instrumento garantidor da supremacia da Lei Fundamental. Todavia foi na Alemanha mesma que se praticaram os desmandos em nome do Estado Constitucional, tendo o período de nazismo oferecido ao mundo o modelo da legalidade sem juridicidade e da normatividade sem legitimidade.

Os traumas políticos e sociais causados pela experiência deste século durante os períodos das Grandes Guerras acabaram por forjar a superioridade do conceito 
material de Constituição a se sobrepor ao conceito formal, que o fetichismo da vontade geral e da lei como sua manifestação excelente apregoava. Constituição não é qualquer norma dotada deste rótulo. É aquela que, legitimamente posta, pode concretizar, na sociedade, a idéia de Justiça que nela se guarda e garante e permite a realização das condições materiais da democracia social. Não basta, pois, a partir de tal formulação, que o Direito não seja afrontado pelo Estado; é preciso que o Direito legítimo seja tornado possível, inclusive pela prestação de serviços públicos que materializem as condições sociais e instrumentalizem os indivíduos e que se cunham, então, como direitos de todos.

3 - As décadas de setenta e oitenta burilam uma nova onda no movimento constitucionalista que se projeta a partir da Segunda Grande Guerra. Não apenas novos direitos são constitucionalizados, mas há uma tentativa de se dar uma nova dimensão ao conceito e à experiência constitucional. A necessidade de se engajar o Direito e, basicamente, a Constituição às demandas sociais e às novas práticas políticas e de torná-la mais aberta e habilitada a responder aos reclamos objetivos e cada vez mais expandidos da sociedade forçam um novo momento do constitucionalismo. As Constituições que se promulgam, tanto na Europa quanto na América do Sul, e que sobrevêm a períodos negatórios do Estado de Direito e falhos de sistemas jurídicos democráticos, demonstram a imprescindibilidade da experiência constitucional.

4 - Mas a década de oitenta mostra um processo de mudanças no Estado, desenvolvidas no sentido inverso ao que o constitucionalismo parecia apontar. Se os direitos sociais e mais aqueles denominados de terceira dimensão, tais como o direito ao meio ambiente saudável, o direito ao desenvolvimento equilibrado, o direito à paz, o direito sobre o patrimônio comum da humanidade e o direito de comunicação passaram a ser buscados mesmo no plano constitucional, uma proposta ou, o que é mais, uma nova imposição se começou a fazer sentir na ordem econômica: a que forçava a lex mercatoria sem regulamentação e sem a presença do Estado no plano das experiências políticas. A prioridade dos mercados e suas leis a enfatizar a presença de consumidores para a obtenção de mais lucros, de um lado, e a sua inserção na prática política dentro do Estado ou mesmo acima dele, por outro, ensejaram o que se deu a conhecer como a tendência neoliberal do processo de globalização. Note-se que não se cuida, aqui, de renegar o mercado como organização que guarda inequívoca importância na organização da sociedade ocidental e mesmo mundial e na dinâmica da vida econômica. O que se põe em relevo, contudo, é que o mercado há que estar a serviço de metas sociais e não a sociedade a serviço do mercado. Nem a lei do mercado haverá que dominar o homem e conduzir a sua necessidade. Antes, ter-se-ia, então, uma lei totalitária e sem fundamento de humanidade ou de humanismo. E, no entanto, é o homem que deve livremente afirmar a sua necessidade para que em sua direção se conduza o mercado. Principalmente, haverá que se elaborar sempre um Estado de Direito e um Direito do Estado no qual o homem não seja a moeda, mas o proprietário dela. Seja o homem o valor maior da vida social e não mero valor de troca por produtos.

5 - Se a Constituição não é uma obra construída ou fechada, mas um processo em construção permanente (podendo mesmo ser entendida como uma obra sempre 
inacabada até mesmo por ser aberta - como de resto o é a própria democracia cuja realização continua a ser por ela buscada - ) há de se considerar que os novos rumos que se pretendem imprimir aos projetos do Estado contemporâneo e que seriam considerados pelo novo constitucionalismo seriam, em sua amostragem mais primária, menos políticos, sendo menos o político menos juridicizado. Desconstitucionalizam-se direitos, desregulamentam-se relações econômicas e sociais, desestatizam-se serviços e empresas que os prestavam por serem considerados públicos e necessários, em sua fundamentalidade, à sociedade.

Como processo que é - e é certo que todo processo é dinâmico - o constitucionalismo movimenta-se sem linearidade, tal como a dança histórica da sociedade, havendo progressos e retrocessos em termos de conquistas de direitos, aperfeiçoamentos e atrasos nas estruturas esposadas nos sistemas. Mas o constitucionalismo aberto que se oferece a prevalecer presta-se à interpretação permanente, para se manter atualizada e coerente com as aspirações da sociedade, mas ainda dotada de rigor que permita impor-se como obra que oferece segurança - ainda que à base da fluidez que se vive - como fim último e necessário do direito. A necessidade de haver interpretação constitucional e a necessidade de se dotar o sistema normativo fundamental de instrumentos e de vias para a ocorrência daquela interpretação oficial-estatal em caso de conflito na sociedade acabou conduzindo ao que já se chamou de neopositivismo, qual seja, o positivismo jurisprudencial. ${ }^{1}$

Vozes alevantam-se pregando o Estado mínimo, que o neoliberalismo tão bem casa com a globalização econômica, ensaiada de passo com o neocolonialismo a buscar mercados em praças nas quais os consumidores não estão saturados de bens que se lhes oferecem segundo as conveniências dos produtores e não de seus reclamos pessoais e sociais. Para um Estado mínimo... uma Constituição mínima. Tanto melhor para a proposta que a economia neoliberal sugere e busca impor. Quanto menos leis de Direito mais leis de mercado. De um mercado que fica mais fácil em seus fins sem leis que não sejam aquelas que se afirmam pelo lucro. Mas a sociedade fica despojada de seus valores éticos, que se convertem, no constitucionalismo, em princípios de direito a garantir a dignidade humana em sua dimensão mais plena e em sua proposta mais universal.

Por isto, mesmo vivendo uma transformação no idêntico curso daquela que assoma a sociedade e o Estado, bem como todas as dimensões e aspectos das relações sócio-políticas e econômicas, é certo que a Constituição, como Lei Fundamental de um Estado, continua a ser essencial. Se as mudanças que lhe contornam novel e ainda pouco nitidamente as funções e as feições são difíceis de ser vislumbradas com tranqüilidade por causa do seu inacabamento e, mais ainda, pela falta de distanciamento do estudioso da tormenta histórica de que se é ator, é imperioso notar que é esta agilidade a que se propõe ela que a torna dada à atualização incessante. E esse processo que se inaugura no tumulto de tantos novos conflitos, ideologias que se sobrepõem sem o pleno saber e sabor de quais seriam, do que aportam de

1 Cf. CANOTILHO, J.J. Gomes. Direito Constitucional e Teoria da Constituição. Coimbra: Almedina, 1998, p. 1198. 
novo e de velho. do acabado e do já arruinado. da busca de retorno a práticas liberais oitocentistas e colonialistas quinhentistas. sugere a sua plasticidade para fazer-se obra que comporta que os conflitos e os embates ideológicos, sociais, principiológicos ainda se possam vivenciar sem que a sociedade se tenha que despedir da civilização. o que seria o retorno à barbárie e ao caos.

6 - O novo constitucionalismo, que mais pressente que sente uma onda inédita de sua experiência (fase a que alguns denominaram de "pós-moderna" à falta de epíteto mais apropriado e preciso). começa a aparecer como uma mudança que pode reconfigurar os próprios fundamentos do direito até aqui experimentado. Teve-se por adjetivado um constitucionalismo liberal, um constitucionalismo democrático social, que superou. ampliando, aquela fase preliminar do período moderno, e o Estado de Justiça Constitucional veio dominar, com a sua proposta de uma juridicidade social democrática, uma maior concretização daqueles valores no Direito. $\mathrm{O}$ momento agora permite ou impõe a juridicidade democrática impregnada dos valores éticos, que se orientam pela participação pluralista voltada ao aperfeiçoamento do princípio da solidariedade social. Este constitucionalismo é, essencialmente, integrativo e não excludente; é universalista e solidário e não elitista e solitário como já o foi no período do liberalismo, que agora se pretende reinaugurar travestido de globalização neoliberal.

Enfim, o novo constitucionalismo é o da ética democrática justa e social, fundada nos princípios da participação pluralista, solidária e ativa, organizada para absorver e não para excluir pessoas, grupos e povos. É o constitucionalismo da ética da solidareiedade de uma sociedade pluralista, poder-se-ia afirmar, a dizer, aquele que é libertador e igualizador, promovendo uma arquitetura jurídica que una pessoas e povos para resguardar a individualidade sem individualismos e a identidade dos povos sem segregação e isolacionismo de grupos. O constitucionalismo contemporâneo expõe-se à abertura e ao intercâmbio e complementariedade com outros ramos do conhecimento, como sejam, a política, a economia, a bioética, dentre outros. Não se faz, assim, uma interseção do Direito, como antes se pretendeu, mas a sua integração com os ramos do conhecimento humano que sejam pertinentes aos temas de seus cuidados.

7 - Esse novo constitucionalismo tem como um de seus mais tensos desafios as novas fórmulas de convivência entre os Estados. Os homens reúnem-se, associam-se, viajam-se. Os Estados, formados à sua imagem e semelhança, também. As uniões e a integração de Estados sugerem novas formas não apenas de convivência e cooperação das instituições, mas para tanto urge se cogitem e se dêem à prática novas formas de elaboração e aplicação do Direito a prevalecer sobre as relações travadas nestas entidades integradas.

O de que se cogita é: estamos seguindo em direção a uma nova idéia de Constituição, uma que teria natureza supraestatal e que poderia estar na base do direito comunitário, quiçá do direito da integração? Para uma nova cidade política supraestatal e para uma nova cidadania - a de cunho mundial - haverá que haver um novo direito. A questão é saber se para esses direitos fundamentais supraestatais haverá também um direito constitucional europeu, um direito constitucional sul-americano etc. 
O Parlamento europeu já adotou um "projeto de Constituição para a União Européia". enquanto a Corte de Justiça de Luxemburgo considerou que o Tratado de Roma deve ser visto como "uma Carta constitucional de base", mas o que aqui se tem é tão-somente a adoção do nome por analogia material, vez que, formalmente, não se há falar em Constituição pela ausência de um poder constituinte elaborador da Lei Fundamental, mas de órgãos estatais competentes para a assinatura dos Tratados. Esses têm natureza jurídica, matéria, forma e eficácia absolutamente diversas daquela.

Mas a abertura do direito constitucional para os atos constitutivos das entidades internacionais, para as organizações regionais integrativas de Estados e para as entidades constituídas em comunidades supraestatais e as mudanças do direito internacional, que tem a sua matéria inserida no sistema normativo constitucional, também são dados inegáveis da realidade.

Novos direitos ou novas faces e formas de aplicação do Direito são postos no bojo das mudanças que ao estudioso do tema deve preocupar e dominar a sua atenção.

\section{II - Constituição e direito supranacional}

9 - Teve-se como certo, até há pouco, que o Estado Democrático de Direito era questão "interna", pertinente a cada povo. O Direito tomava-se como a manifestação mais próprio do poder estatal soberano titularizado por um povo. Assim também a Democracia, que se acreditava obra exclusiva e estanque de cada povo sem tocar preocupações ou atenções de outro.

Como acima encarecido, o sistema democrático de vida fez-se direito fundamental não apenas de todos os povos, mas, principalmente, de todos os cidadãos. $\mathrm{Na}$ terceira onda de direitos fundamentais, a democracia aflora em suas projeções e em seus princípios como pauta preferencial inerente a todos. Como os demais direitos fundamentais, deixou o regime político de ser uma "questão interna" de cada sociedade estatal. Tornou-se um ponto de importância transcendente para todos os homens, todos os grupos, todos os Estados.

Quando o que se põe à preocupação e à atenção de um Estado repercute em todos os demais, todos se têm por atingidos na matéria com a qual guarda relevância a sua experiência. É o que ocorre com a Democracia. Atentados praticados contra ela vêm em feixes e acabam atingindo um conjunto de instituições e mesmo de Estados.

O tema e a prática do Estado Democrático de Direito passaram, então, a ser buscados em conjunto, em sistemas de direito que se aproximam quanto aos princípios e, inclusive, que se influenciam, na igual medida em que os povos acabam por se irmanarem em suas desigualdades para se complementarem.

Tal situação é a base de uma prática jurídica que se apresenta e se acrescenta a cada dia mais acintosamente: aquela que mostra uma nítida e progressiva interconexão entre o direito interno e o direito internacional.

Dois movimentos parecem dar suporte a tal situação: por um lado, os sistemas internacionais, particularmente no que concerne aos direitos humanos, ampliam-se 
e amalgamam-se de modo a dar-lhes maior eficácia; reforçam-se no que é comum e complementam-se no que algum guarda diversidade do outro, pois acaba deste extraindo novas idéias e normas que começam a ser adotadas nos ordenamentos nacionais. Doutra parte, a integração econômica e política traduz-se em normas que se positivam no plano das relações entre Estados mas que se realizam no plano interno de cada qual deles, donde a necessidade de ser harmoniosa e eficaz a interconexão entre os dois sistemas.

Nota-se, então, a imprescindibilidade de o Direito Constitucional abrir-se não mais apenas no plano interno - para as organizações sociais e políticas no Estado -, mas também no plano externo - para a maior integração e coordenação dos sistemas de direito diferenciados (porque nacionais e próprios dos diferentes povos) numa nova ordem jurídica interestatal. É, ainda, de se considerar que se tem por superada ou, pelo menos, desprezada a visão que se admitira, anteriormente, de serem as normas internas ou internacionais meros fatos uma em relação à outra.

Cogita-se, então, da constitucionalização do direito internacional, pela qual os sistemas jurídicos fundamentais passam a absorver normas daquela matéria, inclusive no que concerne à forma de serem recebidas, no ordenamento interno, aquelas que advenham de tratados internacionais ou de atos que se lhes sigam e, no plano do direito comunitário, aquelas que a elas se sobreponham.

À parte idéias que se punham nas teorias monistas, pela qual se teria o princípio de identidade de Direito Internacional e de Direito Interno, a formar bloco único de normas jurídicas, é certo que a coordenação das ordens faz-se mais e mais presente e necessária. Direito não comporta e nem suporta contradições, o que lhe custaria, inclusive, a efetividade jurídica e social.

Há quem se refira, ainda, à internacionalização do direito constitucional, proposição segundo a qual as normas conformadoras do sistema de direito internacional passariam a operar e a dotar-se de eficácia no plano interno pela recepção automática do quanto regulamentado por meio de tratados, protocolos, acordos etc. O direito constitucional internacional seria, então, considerado mesmo um ramo do direito constitucional, o qual "não é um ramo autônomo da Ciência Jurídica, mas apenas uma divisão do Direito Constitucional...o Direito Constitucional Internacional tem um núcleo mínimo: conclusão de tratados, declaração de guerra e celebração da paz. Enfim, não se pode dizer que ele tenha um objetivo próprio. ...O Direito Constitucional Internacional é a tentativa de adaptar a Constituição à ordem jurídica internacional que se sobrepõe a ela. A Constituição é a manifestação da soberania estatal e o DIP a sua negação ou, pelo menos, a sua crescente limitação." ${ }^{2}$

O Direito Constitucional, como o Direito Internacional, dota-se de conteúdo essencialmente político. Ora, à medida que o político (e a política) nacional aproxi-

2 Cf. MELLO, Celso de Albuquerque. Direito Constitucional Internacional. Rio de Janeiro: Renovar, 1994. p. 31. Saliente-se que aquele autor entende que "não existe um D. Constitucional Internacional por falta de um objeto definido e método próprio. O que existe são normas constitucionais de alcance internacional que devem ser analisadas em cada caso procurando compatibilizar os dois ramos da Ciência Jurídica." (Ibidem) 
ma-se, cinge-se, soma-se, coordena-se, cada vez mais, com o político (e a política) internacional, em que as decisões em um plano repercutem, imediatamente, no outro, é certo que o direito interno, e, aí, basicamente, o constitucional e o direito internacional passam a constituir feições mais próximas da matéria jurídica, a qual busca, fundamentalmente, a unidade para maior eficácia e segurança. Muito própria é a ênfase que alguns autores deram à unidade do Direito, o qual, no dizer de Gerson Boson, dentre outros autores, "é o reflexo de uma dada época. O Direito público e o Direito público internacional são o produto de um mesmo ambiente histórico. ... O homem não possui duas consciências jurídicas, lado a lado, uma do Direito interno e a outra do Direito internacional. A consciência jurídica do homem é uma só." 3

É certo que esta mesma e única consciência do Direito que uma sociedade possui e se põe em determinado momento histórico não produz, contudo, normas, que, em sua hierarquia e diversificação material e formal, fiquem acima de dúvidas em sua incidência e em sua execução.

Pelo que a interconexão do sistema de direito constitucional e do direito internacional põe-se como objeto do tratamento do direito interno, resguardada, ainda hoje, a questão da soberania da vontade popular manifestada, incontrastavelmente, em sede de poder constituinte, quando da elaboração das normas fundamentais.

10 - Muito se tem criticado a Constituição da República brasileira no cuidado a ela dado ao tema que pertine ao direito internacional. ${ }^{4}$

Os argumentos que se alevantam quanto ao conservadorismo do modelo constitucional brasileiro repousam na circunstância básica de que se teria adotado no sistema princípios e preceitos clássicos sobre as normas formuladas no plano internacional dos tratados, acordos e atos internacionais apenas mediante a prévia decisão de sua entronização no direito interno pelo Congresso Nacional (art. 49, I, da Lei Fundamental do Brasil).

Parece que dois pontos merecem ser enfatizados nessa passagem: $a$ ) o primeiro se refere às relações entre as normas constitucionais e infraconstitucionais e aquelas havidas ou decorrentes de tratados, acordos e atos internacionais e $b$ ) o segundo concerne aos princípios constitucionais brasileiros referentes às relações e aos atos internacionais.

a. 1) Quanto ao primeiro tópico, é de se considerar a inexistência do princípio da recepção automática das normas de direito internacional no sistema nacional.

3 BOSON, Gerson. Constitucionalização do direito internacional. Belo Horizonte: Del Rey, 1996, p. 155.

4 "Pode-se observar que a nossa Constituição consagra uma das antinomias da ordem internacional: a soberania e a cooperação internacional vez que esta só se realiza às expensas daquela. ...

Como se pode concluir a Constituição do Brasil não leva em consideração as novas tendências da ordem jurídica internacional." (MELLO, Celso de Albuquerque. Op. cit., p. 122) O mesmo autor ainda enfatiza que "Quanto à Constituição brasileira no tocante às normas de alcance internacional podemos dizer que é bastante falha e que quase sempre não se adapta às exigências das relaçōes internacionais atuais. Nesta matéria a nossa Carta Magna é tradicional e sem inovaçōes". (Ibidem)

Cf. também REZEK, Francisco. Conferência In Direito Comunitário do Mercosul. Porto Alegre: Livraria do Advogado, 1997, ps. 52 a 61 . 
Diversamente do que ocorre em outros sistemas. tais como o alemão e o português. dentre outros, a Constituição Brasileira não permite que as normas do direito internacional geral ou comum e aquelas resultantes de tratados sejam diretamente aplicáveis no Estado brasilciro. Nos ordenamentos que adotam aquele princípio as normas de direito internacional vigoram internamente tão logo adquirem vigência no plano internacional. independente de qualquer ato dos poderes públicos nacionais que as transformem em normas de natureza interna. ${ }^{5}$

No modelo abrigado na Constituição da República brasileira, compete ao Congresso Nacional "resolver definitivamente sobre tratados, acordos ou atos internacionais que acarretem encargos ou compromissos gravosos ao patrimônio nacional" (art. 49, I). Mantém-se, portanto, no ordenamento brasileiro o princípio da superioridade do direito interno sobre o direito internacional. ${ }^{6}$

É certo que tal interpretação e aplicação do direito interno em relação ao direito internacional decorre não apenas da literalidade das normas do sistema, mas, principalmente, da interpretação que a elas se dá especialmente pelos tribunais. ${ }^{7}$ Não que a presença de normas constitucionais determinantes da sua supremacia e da primazia das demais normas que compõem o ordenamento jurídico pátrio possa ser desconsiderado pelos seus aplicadores, especialmente do Poder Judiciário. Mas parece. contudo, igualmente exato que a mutação constitucional pode permitir a adaptação das normas do sistema independentemente de sua modificação formal a partir de princípios que se reinterpretem e que se dêem à renovação. A modificação da cultura constitucional é importante para a permanente atualização da Constituição. A transformação do pensamento jurídico pela abertura também do intérprete tem papel insubstituível no processo de arejamento do sistema de Direito. Não basta que uma Constituição tenha um texto aberto, que se oferece a interpretações constantemente renováveis; é, igualmente, necessário que o intérprete seja aberto a novos contextos.

A questão da interconexão do direito interno e do direito internacional põe-se, assim, no plano da hierarquia e das fontes das normas jurídicas, a saber, aquelas que conformam o direito interno e aquelas que advém do direito internacional.

Freqüentemente se tem a questão da hierarquia das normas para se optar pela teoria dualista ou pela monista apenas se considerando a qualidade soberana do Estado que elabora e positiva o direito constitucional.

5 A Constituição alemã estabelece. em seu art. 25. que " as normas gerais do direito internacional público são parte integrante do direito federal. Estas normas possuem primazia perante as leis e constituem fontes diretas de direitos e obrigaçōes para os habitantes do território federal".

Norma análoga se contém no art. $8^{\circ}$ da Constituiçāo portuguesa.

6 Cf. BOSON, Gerson. Op. cit., p. 158, segundo o qual "a grande maioria dos doutrinadores e publicistas contemporâneos defende, à luz de vários e ponderáveis argumentos, a supremacia do Direito internacional sobre o Direito interno."

A jurisprudência dos tribunais brasileiros, inclusive o Supremo Tribunal Federal, reiteradamente tem declarado a prevalência do direito interno sobre o direito internacional, declarando-se até mesmo a inconstitucionalidade de tratado e a sua inaplicabilidade quando contrariar norma infraconstitucional.

7 Neste sentido. e relativamente ao Mercosul. afirma Francisco Rezek que "na cabeça, por exemplo. dos juízes basileiros. até agora, nada mudou". (Conferência cit.) 
Ocorre que se há de considerar aquela condição de soberania não apenas da pessoa estatal, que positiva o direito da entidade política, mas principalmente do poder do qual se origina a Constituição do Estado. É que o exercício da titularidade do poder constituinte tem a qualidade de soberano que o faz sobrepor-se aos poderes constituídos. É a esses que o poder constituinte confere, segundo os seus termos e limites, o direito de estabelecer as relações internacionais. Logo, enquanto as normas constitucionais derivam de um poder constituinte soberano, as normas de direito internacional com as quais acordam os Estados nascem de atos do poder constituído. Esse é sempre limitado e condicionado pela obra do constituinte e dele não pode desbordar.

É certo, então, que quando o poder constituinte determina que a resolução definitiva sobre tratados e atos internacionais deve ser feita pela decisão do poder legislativo, por exemplo, tal como se dá no caso brasileiro, parece certo considerar-se que a superveniência daqueles com a sua transformação em norma de eficácia interna, por força do cumprimento constitucional relativo à decisão sobre o tema, importa em que não haja a superioridade de uma norma de direito interno contra a qual aqueles não possam prevalecer. Aqueles podem modificar a norma jurídica de direito interno e sobre ela haverá de prevalecer.

Também não parece certo supor-se que a superveniência de lei, que é elaborada por um órgão do poder constituído exatamente de igual natureza e hierarquia daquele que resolve sobre o tratado, atos e acordos internacionais, possa modificá-lo. É que a vertente do ato de direito internacional implica numa relação entre entidades estatais que não podem recuar, singelamente, numa primeira decisão por meio de um ato unilateral, como o é o legislativo, independente das condições e consequiências que daí advenham para os demais participantes do tratado ou acordo. Se a retirada de um Estado de um tratado tiver que ser feito tanto haverá que se dar segundo os termos de direito internacional combinados com os de direito interno e não mediante a simples elaboração e promulgação de uma lei pelo órgão competente.

Não parece, pois, que o ato de direito interno prevaleça sobre o ato de direito internacional ao ponto em que se pretende tornar esse mero fato sem qualquer obrigação dele advinda, porquanto produzido na pendência de uma relação em que há interesses de outras entidades estatais igualmente soberanas. Tanto vale mesmo em sistemas como o brasileiro que adota um rigoroso exame da compatibilidade das normas de direito internacional com as normas de direito interno.

Diversamente é a situação quando a interconexão do direito interno com o direito internacional põe os olhos sobre uma situação de conflito entre as normas constitucionais e as internacionais. É que estas. como antes lembrado, decorrem do comportamento do poder constituído, competente para formulá-las, aceitá-las e adotá-las, enquanto aquelas decorrem do poder constituinte, que se põe com supremacia sobre aquele.

Mesmo no que concerne ao poder constituinte derivado, como é o reformador, parece indisputável que a teoria da constituição, que se põe no fundamento do poder constituinte, ficaria capenga se nela se introduzisse o entendimento segundo o qual um ato simples e despojado das garantias que o poder constituinte impõe à ação do constituinte reformador poderia desconhecer os limites formais para a mudança 
constitucional e acolhesse normas materialmente constitucionais sem o atendimento dos pressupostos, condições e limites que se traçam para a reforma da Lei Fundamental. $O$ poder constituinte derivado de reforma seria, então, hierarquicamente subordinado à competência para a edição das normas de direito internacional internalizadas. Tanto seria um limite implícito material ao seu exercício, mas não apenas, porque transformador da sua própria natureza supralegal.

Daí porque, no sistema constitucional brasileiro, salvo nos casos em que a Constituição expressamente considere o tratado fonte do direito de nível constitucional, tal como se dá, por exemplo, no art. $5^{\circ}$, parágrafo $2^{\circ}$, é certo que ele não pode ser considerado válido senão quando compatível, adequado e coerente com a Lei Fundamental.

Daí também porque a Constituição brasileira explicitamente estabelece o sistema de controle de constitucionalidade das leis e atos normativos inclusive daqueles havidos em tratados. Tal controle, que se põe no plano da competência concentrada, nos termos do art. 102, I, a, e, ainda, da competência difusa (art. 102, III, $c$ ), pode ensejar a apreciação da matéria pelo Supremo Tribunal Federal, demonstrando que o princípio da sindicabilidade judicial dos atos fundados em tratados também constitui direito público subjetivo fundamental do indivíduo no sistema brasileiro.

Mais ainda, até mesmo o controle de legalidade dos tratados vêm sendo feito pelo poder judiciário brasileiro e é nesse ponto que surgem os principais conflitos persistentes até agora quanto à matéria.

a.2) Uma palavra há de ser dita relativamente à questão da interconexão entre normas de direito interno e normas supranacionais quando se trata do direito comunitário.

Característica do direito comunitário é, exatamente, o de compor uma ordem supranacional (melhor, talvez, seria afirmar supraestatal), porém de imediata incidência no plano do ordenamento jurídico interno das entidades que componham a comunidade.

É que esse é considerado um direito primário e não derivado, a dizer, não se o considera uma criação extraestatal, mas uma elaboração e adoção do próprio Estado que é parte dos órgãos que o cria, à maneira do que se dá na Comunidade Européia, por exemplo. Daí porque não se há cogitar, na espécie, do princípio da recepção, solucionando-se a questão referente à validade jurídica da norma pelo princípio da subsidiariedade. A autonomia decorrente da primariedade da criação do direito caracteriza-o, dotando-o de positividade e eficácia direta como componente do ordenamento jurídico vigente no Estado.

É de se considerar que o direito comunitário caracteriza-se pela ênfase no princípio da igualdade dos Estados formadores da comunidade, no bojo da qual ele nasce; pelo princípio da reciprocidade, porque se não houver correspondência estrita entre as competências que cada qual das entidades partes transfere ao órgão supranacional do qual ele emana haverá um desequilíbrio que descaracteriza a própria base da Comunidade; e pelo princípio da solidariedade pelo qual se fundamenta a busca de um conjunto de elementos que amainem as diferenças existentes nas diversas entidades. 
Nesse ramo do direito que se realiza nas Comunidades de Estados formando uma nova condição supraestatal diferenciada das meras reuniões eventuais tratadas entre entidades estatais, não se discute o conflito entre direito interno e direito comunitário, porque eles se coordenam à maneira de uma figura projetada em épuras que se compõem formando um núcleo e um desdobramento afirmados pela unidade.

De se notar que o Mercosul não produz direito comunitário, pelo que ao conflito de normas aplicáveis aos Estados considerados partes dele não se resolvem segundo os princípios e características deste ramo jurídico, mas no quadro próprio das relações direito interno e direito internacional, havendo tão-somente um encaminhamento diferenciado, em alguns casos, quanto à interpretação e à aplicação das normas específicas da integração, que já vem sugerindo a especialidade do seu tratamento, porém e ainda, no âmbito daquele.

a.3) Assim, diversamente do que ocorre quanto ao direito comunitário dá-se com o denominado direito da integração ou direito integracionista, considerado, por alguns, uma especialidade do direito internacional ${ }^{8}$, enquanto outros cogitam-no como especialidade do direito constitucional ${ }^{9}$. Os princípios e características são, portanto, os destes ramos, internacional ou constitucional, sem qualquer autonomia ou singularidade das normas integracionistas. Note-se que a referência à inserção do direito da integração em um ou outro ramo (do direito constitucional ou do direito internacional) depende, fundamentalmente, da fonte das normas referentes ao tema de que se cuida (internas ou internacionais) e, pois, da perspectiva a partir da qual se enfoca a situação cuidada.

Não há confusão entre o direito comunitário e o direito da integração. Aquele tem natureza, fonte, objeto e características diversos do direito internacional, porque próprio de uma Comunidade de Estados que afirmam um elo formador de uma composição política supraestatal porém não estranha ao Estado. Já o denominado direito da integração é, reafirme-se, o conjunto das normas de direito internacional formuladas e aplicáveis no processo de integração dos Estados conformadores de uma pessoa jurídica de direito internacional derivada da integração das partes e que são recepcionadas no ordenamento interno.

A cooperação e a integração afirmam-se, inclusive, para que os objetivos comuns sejam superiormente cumpridos pelo conjunto das entidades estatais. Para que se dê a integração haverá de serem racionalizadas e formalizadas aquelas finalidades, pois é delas que se extraem os processos a serem adotados na estrutura e na organização da pessoa jurídica de direito internacional, a qual atuará para que se obtenha a eficiência dos procedimentos tidos como próprios.

No processo de integração os Estados partes não se vinculam, necessária e automaticamente, às decisões, às quais se chega por consenso (cf., por exemplo, o art. 37, do Protocolo de Ouro Preto, relativo ao Mercosul, pelo qual "as decisões

8 Cf. MELLO, Celso de Albuquerque. Direito internacional da integração. Rio de Janeiro: Renovar, 1996.

9 Cf. DROMI, Roberto; EKMEKDJIAN, Miguel; RIVERA. Julio C. Derecho comunitario. Buenos Aires: Ciudad Argentina, 1995. 
dos órgãos do Mercosul serão tomadas por consenso e com a presença de todos os Estados-Partes").

A tomada de decisões por consenso e com a presença de todos os Estados-Partes demonstra a carência de independência da entidade de direito internacional que forma o Mercosul, diversamente do que se dá com a Comunidade de Estados, consequientemente, para o direito prevalecente em um e os atos mesmo que de natureza normativos estabelecidos no outro caso.

Por conta mesmo desta condição de serem as decisões tomadas no processo de integração vinculadas às deliberações independentes e soberanas dos Estados não se forma um direito supranacional de aplicação direta, automática e imediata em cada qual deles, como se dá no direito comunitário. Não se cria, no âmbito do processo integracionista, um direito comum aos Estados, mas uma criação comum de um direito que cada qual dos Estados estudam e decidem quanto à vigência e aplicação na esfera de suas competências soberanas. Por isso as decisões adotadas pelos órgãos do Mercosul podem ser formalizadas como normas, mas a sua natureza distingue-se das leis quer do ponto de vista da fonte, quer do ponto de vista da forma, quer do ponto de vista dos efeitos.

Como o direito, para ser dotado de eficácia, depende de órgão controlador de sua validade e aplicação que se dote de competência sancionadora para a hipótese de seu descumprimento e de competência impositiva de comportamentos em caso de inobservância de suas decisões, é imprescindível pensar-se, no direito comunitário, de um órgão supranacional dotado de competência jurisdicional definitiva, tal como se dá com o Tribunal de Luxemburgo. Norma sem jurisdição de igual natureza e âmbito de incidência correspondente ao de sua fonte não tem essência jurídica, não guarda o vigor que no Direito se deve conter e não produz os efeitos que justificam a sua existência nessa condição. No âmbito do processo de integração de Estados, como não se tem um direito comunitário também não se tem um órgão judicial que possa dotar as suas decisões de vigor formalmente jurisdicional. Tal como inexistindo um Parlamento ou órgão legislativo dotado de competência para criar o Direito não se há de pensar em lei — com a qualificação e a caracterização que lhe são próprias - também sem um órgão judicante dotado de competência para firmar, em caráter definitivo, uma decisão judicial não se tem a garantia de eficácia daquelas decisões acolhidas supranacionalmente.

O Tribunal Internacional de Conciliação e Arbitragem do Mercosul (TICAMER) tem competência para arbitramento, o que o distingue da jurisdição pensada e ainda hoje prevalecente com a natureza definitiva que a sua prestação impõe. Daí porque também quanto a este elemento se pode observar a distinção entre o direito comunitário e o que ele provoca em termos de organização da estrutura e da organização da Comunidade de Estados e o direito internacional da integração.

Repita-se: neste quadro do processo de integração eventuais conflitos entre normas de direito interno e de direito integracionista solucionam-se segundo as regras do direito internacional, apenas especializando-se a sua interpretação e aplicação às condições que singularizam a condição dos Estados-Partes.

b) O segundo ponto que reclama breve passagem d'olhos refere-se ao conjunto de princípios que se contém na Constituição da República especialmente no que concerne às relações entre o Estado brasileiro no plano do direito internacional. 
Inserido o tema no título I da Lei Fundamental, dentre os princípios fundamentais do Estado Democrático de Direito em que se constitui a República Federativa do Brasil, arrolam-se aqueles que concernem às suas relações internacionais.

b.l) Dispõe o art. $4^{\circ}$ e seu parágrafo único:

"Art. 4" - A República Federativa do Brasil rege-se nas suas relações internacionais pelos seguintes princípios:

I - independência nacional;

II - prevalência dos direitos humanos;

III - autodeterminação dos povos;

$I V$ - não-intervenção;

$V$ - igualdade entre os Estados;

$V I$ - defesa da paz;

VII - solução pacífica dos conflitos;

VIII - repúdio ao terrorismo e ao racismo;

$I X$ - cooperação entre os povos para o progresso da humanidade;

$X$ - concessão de asilo político.

Parágrafo único. A República Federativa do Brasil buscará a integração econômica, política, social e cultural dos povos da América Latina, visando à formação de uma comunidade latino-americana de nações".

As normas contidas no art. $4^{\circ}$ da Constituição da República não são as únicas que se referem ao domínio das relações internacionais. Importantíssima nesta matéria é, por exemplo, aquela que se contém na parte final do parágrafo $2^{\circ}$, do art. $5^{\circ}$, que oferece precioso subsídio para a interpretação do sistema.

Principalmente, é de se ter em conta para a correta interpretação do dispositivo em causa que ele se insere em título de "princípios fundamentais", os quais têm que ser, necessariamente, tomados em seu conjunto.

Ademais, não se há de desprezar o preâmbulo da Constituição, o qual, conquanto não tenha natureza de norma constitucional, é uma ótima bússola jurídica a guiar o intérprete pelos caminhos pré-traçados pelo poder constituinte.

Assim, não se pode deixar de considerar a ênfase nele oferecida à circunstância de que a elaboração constitucional destina-se a assegurar o exercício dos direitos descritos e implícitos no sistema segundo "valores supremos de uma sociedade fraterna, pluralista e sem preconceitos, fundada na harmonia social e comprometida, na ordem interna e internacional, com a solução pacífica das controvérsias...".

As normas contidas no art. $4^{\circ}$. da Constituição da República têm natureza de princípios, mas nem por isso se poderia considerar, por mero e desarrazoado equívoco, serem elas de eficácia limitada ou sem vigor para produzir efeitos concretos.

Até se poderia alegar que não se teria instrumentalizado o cidadão para forçar os poderes da República a dar concretude aos princípios ali incluídos. Talvez o 
cidadão não tenha, efetivamente. recebido instrumentos constitucionais específicos para forçar a tomada de uma ou outra decisão numa direção predeterminada. Todavia, é certo que ele dispõe de instrumentos constitucionais e processuais para requerer dos poderes competentes a anulação de comportamentos públicos que contrastem ou desatendam os princípios definidos no dispositivo em pauta. Destarte, qualquer regência das relações internacionais firmadas pela República que seja contrária ou desconforme ao quanto constitucionalmente afirmado é inválida e tanto poderá ser obtido pelo cidadão. Neste sentido, portanto, o cidadão tem instrumentos jurídicos para determinar a plena eficácia das normas do artigo, conquanto predominantemente para impedir a validade de comportamentos que as afrontarem. ${ }^{10}$

b.2) Cabe uma palavra especial, no presente estudo, quanto ao parágrafo único do art. $4^{\circ}$, da Constituição da República brasileira.

Tem-se, ali, a constitucionalização do sonho da pátria grande latino-americana. Ela deixou de ser apenas ilusão de idealistas para se converter em diretriz fundamental da República no sentido de se fazer real o quanto antes apenas pensado.

A norma do parágrafo único do art. $4^{\circ}$ não contém apenas mais um princípio, mas uma norma constitucional de conteúdo específico trazendo uma ordem a ser cumprida pela República, a qual "buscará a integração ...". O objetivo da integração também é posto de forma expressa, a saber, "a formação de uma comunidade latino-americana de nações". Significa afirmar que a integração é considerada opção constituinte originária delimitadora do modelo de Estado acolhido. Não o Estado isolado ou isolacionista, não o Estado mimetizado por comunidades ultramarinas ou não latinas, mas o Estado voltado à formação de uma comunidade especificada pelo constituinte.

Do texto constitucional específico ressaem alguns elementos cuja ênfase se mostra necessária: primeiramente, é de se relevar, com Rui Barbosa, que "quem dá os fins, dá os meios", e que, também na fórmula daquela jurista, "a Constituição não dá com a mão direita para tirar com a esquerda". Se ela configurou, constitucionalmente, em seus fundamentos, uma República Democrática de Direito afetada à integração para a formação de uma comunidade latino-americana de nações não se há de extrair, pela via de uma interpretação restritiva, os meios de que ela se terá que valer para que a integração ocorra de maneira eficiente e efetiva. Em segundo lugar, saliente-se que a "formação de uma comunidade latino-americana de nações" não significa apenas um ato formal para se dar cumprimento à determinação normativa, antes é de se interpretar que ali se contém a definição da obrigação republicana brasileira de se buscar a integração para que seja constituída, estruturada e realizada uma comunidade de nações latino-americanas.

Também se há de relevar que a integração buscada não se apega ao fator econômico - que seria a abertura de mercados ou a atividade comercial integrada

10 Opina Celso de Albuquerque Mello que "No Brasil a sensação que se tem é que os princípios (constitucionais) foram escolhidos de modo arbitrário. ... A inclusão destes princípios na Constituição não os torna mais obrigatórios no plano internacional, mas torna mais explícita ou reforça a aceitação deles por parte do estado". (Op. cit., p. 159) 
-. devendo se completar na sua formação política, social e cultural, pelo que não há o cumprimento da norma quando a atenção se voltar ou se se vier ater a um dos fatores, menos ainda aquele que não traz o dado caracterizador da comunidade latino-americana das nações.

Aliás, a palavra nação - muito pouco empregada pela Constituição - denota uma realidade distinta daquela do Estado, realçando-se nela, tal como se contém na teoria, uma comunhão de história, de traços culturais, de crenças e uma perspectiva comum em face do passado aproximado em suas características.

Portanto, a integração buscada pela República com os demais Estados da América do Sul tem fundamento constitucional e embasamento ético-jurídico, vez que posto para um aperfeiçoamento conjunto das realidade econômica, política, social e cultural. Como ensinado por Pe. Inácio Neutzling, "a integração sonhada pelos libertadores é o ponto culminante de um processo de liberação e de desenvolvimento justo e equilibrado da América Latina ... (e) corresponde a um 'processo de integração solidário, que trate de corrigir em forma gradativa os desniveis econômicos entre os países-membros"."

Com base neste parágrafo único deste art. $4^{\circ}$, não se há, pois, considerar que a aplicação do direito internacional da integração do Mercosul pode se dispensar de atentar ao atendimento estrito dos objetivos ali especificados e da determinação ali posta. Tanto equiivaleria ao descumprimento do comando constitucional. Daí porque, fundamentando-se neste dispositivo, haverá que se dar à interpretação e à aplicação dos atos, acordos e tratados firmados no sentido de se dar cumprimento às normas daquele parágrafo, a ênfase e o tom necessários para que as finalidades nelas postas sejam atendidas. O direito internacional da integração do Mercosul tem base constitucional específica, não se generalizando na principiologia das normas relativas ao direito internacional comum.

Constituição interpreta-se para que se lhe dê eficiência e efetividade e não para se conduzir à inocuidade, impossibilidade ou impropriedade de suas normas. A integração para a formação de uma comunidade latino-americana de nações é norma constitucional e a configuração constitucional mesma da República põe-se com esta condicionante no plano das relações regionais da América.

\section{III - Constituição e Soberania no Direito Brasileiro}

"A soberania é o poder absoluto e perpétuo de uma república." - Jean Bodin -

11 - O conceito de soberania é polêmico, relativo, histórico e cada vez mais posto em questão em razão das condições políticas ocidentais atuais.

11 NEUTZLING, Inácio. O Mercosul e a Integração Latino-americana In Mercosul - integração e impacto sócio-econômico. Petrópolis: Vozes, 1997. p. 107. 
Qualidade essencial do poder estatal que o distingue dos demais que se exercem em determinada sociedade política, a soberania não teve o seu aproveitamento na experiência antiga. No Estado concebido e vivido pelos gregos, cogitava-se da natureza autárquica daquela cidade global. Aquele conceito, entretanto, diferencia-se grandemente do que o período moderno concebeu como soberania.

Também os Estados medievais, pluralmente pensados pelos doutrinadores em razão da diversidade de sua organização e dinâmica, não conheceram o conceito moderno de soberania, porque a Igreja é que exercia poder supremo em permanente disputa com o poder daquela organização política. Mas é neste período que começa a se formar a idéia de que o poder estatal depende da imposição de sua condição superior para se impor aos demais poderes que gravitavam em sede política, dai a expressão supremitas. Em 1283 Felipe de Beaumanoir valia-se da palavra soberano para designar o poder supremo do barão em seu baronato.

Coube a Jean Bodin, em sua obra Os seis livros da república, datado de 1576 , considerar e conceituar a soberania (do francês souverainetét ${ }^{12}$ ) $u m$ elemento essencial ao Estado. ${ }^{13}$ Todo Estado teria que contar com aquele elemento para ser assim considerado. Aquele conceito dota-se de característica absoluta na visão do pensador francês. o que, entretanto, foi sendo deixado para trás no Estado moderno, especialmente desde o final do século XIX. Todavia, mesmo no plano das relações internacionais prevaleceu uma concepção de soberania absoluta, preconizada por Vattel no século XVIII e enfatizada, ainda, no século subseqüente.

Da doutrina aristocrática, na qual dormitou desde os seus primórdios até o conceito que elevou o termo à soberania popular o que se modificou, essencialmente, foi a entronização da democracia como regime político. cujos princípios vinculam melhormente os fins do Estado com quanto buscado pelo indivíduo e pelo cidadão.

Soberania é conceito que já foi tido, no conceito normativista, como relativo à ordem jurídica nacional suprema e não subordinada à elaboração de outrem; como o poder político supremo de um Estado; como a independência da entidade estatal em relação aos outros Estados. De qualquer forma, o que hoje se enfatiza é muito mais os seus atributos e o exercício democrático do poder popular em caráter soberano.

Tanto no plano interno quanto no plano internacional a soberania desempenhou e ainda cumpre papel inapelavelmente importante, conquanto hoje já não tanto quanto nos séculos anteriores e no âmbito das relações internacionais menos ainda.

12 Para alguns autores a palavra adviria de "superanus" do latim médio com o sufixo "anus" que a faz remontar à sua origem popular. enquanto outros situam tal origem no baixo latim "superanitas". Mas qualquer que seja a sua vertente é certo que o uso da palavra consolida-se no curso do século XII. tendo enorme importância para a sedimentação do Estado moderno que se contrapõe e se sobrepõe as relaçōes feudais características da Idade Média.

De se notar a liçāo de Dalmo de Abreu Dallari, segundo o qual “embora o conceito de soberania só tenha aparecido a partir do século XVI. a ordem jurídica estatal sempre foi soberana" (O futuro do Estado. São Paulo: Saraiva. 1972. p. 63).

13 "République est un droit de gouvernement de plusieurs ménages é ce Qui leur est commun avec muissance someraine" - Livro primeiro. capítulo I. da obra Les six livres de la République. 
Mas a afirmaçāo do Estado como sociedade política diferenciada das demais organizações. aí incluída a Igreja. que também desempenhavam poderes políticos constituiu elemento de importância incontestável para a informação e a afïrmação do Estado moderno.

Desde o final do século XIX e especialmente no curso deste século houve uma relativização cada vez maior do conceito de soberania. Quer porque as idéias anarquistas e as marxistas passaram a negá-la ensejando o seu questionamento mesmo em outras sedes de pensamento, quer porque a internacionalização de aspectos políticos, econômicos e. mais recentemente, sociais e culturais determinam afinidades entre Estados e a coordenação de políticas públicas, quer porque a presença de organizações não governamentais internacionais apresentam-se como partícipes da experiência política de diferentes Estados, o certo é que a restrição da soberania é um dado da atualidade. ${ }^{14}$

A soberania referida por Bodin foi revisada. ${ }^{15}$ Para alguns publicistas eminentes e influentes deste século, como Duguit por exemplo, haveria que se extinguir o conceito e a crença na soberania para se ter uma nova concepção de Estado. E ainda hoje há quem sustente que "não é exagero dizer-se que o inimigo da paz é o Estado soberano." 16

Também se há de tomar em conta que a soberania popular vem sendo mais encarecida nos sistemas jurídico e político dos Estados democráticos, mantendo-se as suas características de unidade $\mathrm{e}$ indivisibilidade, irrevogabilidade e intransferibilidade.

Se de um lado, o conceito tradicional e hermético de soberania já não mais prevalece, até mesmo porque desatende aos reclamos da sociedade contemporânea, é certo que ela ainda é proclamada, inclusive nas Constituições, por resguardar o direito de cada povo de decidir a sua forma política de ser e de fazer-se construir em sua história de maneira a não se subordinar aos comandos de potências estrangeiras.

No momento presente, em que a soberania é do povo e não de nações e em que as idéias e as ideologias podem irmanar mais que a identidade do solo que constitui a pátria; no momento histórico em que a terra se converte em pátria da totalidade dos homens, em que o meio ambiente atinge a vida de todos os seres do planeta qualquer que seja o local que se tome por referência, há que se pensar, contudo, que a soberania repensada, relativizada e centrada na participação política livre e permanente do povo pode servir ao resguardo da identidade de cada grupo cultural sem

14 Acentua Celso de Albuquerque Mello que "esta (a soberania) passa a ser uma noção quase que formal, vez que seu conteúdo é cada vez mais diminuído pela criação e desenvolvimento das organizaçōes internacionais. Muitas vezes, a própria palavra soberania é evitada, como ocorre na Carta da ONU que prefere usar expressōes como "jurisdição doméstica' ou "domínio reservado"' (Op. cit., p. 122)

15 Cf. BONAVIDES, Paulo. Ciência Política. Rio de Janeiro: Forense, 1993, p. 142.

16 BOSON, Gerson. Op. cit., p. 134. Segundo aquele autor "em toda essa mistela da História. no fundo. com grandeza ou sem esta, sempre encontramos impávido esse tradicional conceito de soberania. com a récua da estupidez humana. ainda mesmo quando cortados os seus vínculos originários com a referida cosmovisāo religiosa politeísta" (Ibidem). 
perda da dimensão universal da convivência política. Mas parece indubitável que a soberania não pode persistir como conceito que se ponha como bloqueio para que venham as modificações que a nova ordem internacional, as novas formas de solidariedade entre os homens nos diversos Estados e a experiência de universalização e mundialização dos direitos fundamentais do homem propõem e põem. Por isso é que se tem enfatizado a desmaterialização cada vez maior da soberania e a sua aceitação sempre mais como conceito formal, que não embaraça nem impede a internacionalização dos contatos e relações entre os Estados e, principalmente, entre os sistemas garantidores dos direitos humanos.

12 - É de Celso de Albuquerque Mello a assertiva de que "na prática, não há Constituição ou jurisprudência de tribunal constitucional que permita a 'alienação' da soberania, porque fazê-lo seria consagrar o fim do Estado. ... Os Estados ainda não estão preparados para o seu suicídio." 17

No constitucionalismo brasileiro o princípio da soberania do Estado aparece, ainda que não com o uso expresso da palavra, em todas as Constituições desde o Império. $^{18}$

Na Constituição de 1988 o princípio da soberania é não apenas expressa como o primeiro dos fundamentos da República Federativa do Brasil no plano interno e no plano internacional (art. $1^{\circ}$, I e art. $4^{\circ}$, I), estendendo-se e reforçando-se a sua condição democrática, pelo que a soberania popular é realçada (art. 14) e a soberania nacional cuidada de maneira explícita (art. 170, I).

$O$ conceito de soberania constitucionalmente abrigado no sistema brasileiro açambarca não apenas o jurídico, vale dizer, a supremacia do direito fundamental interno sobre o direito internacional, como o político (daí o uso da expressão "independência nacional") e o econômico, que se dá por uma ordem voltada a assegurar a independência do Estado nacional em relação aos centros financeiros poderosos que pretendem ou propendem a subordinar a seus particulares interesses o comando das políticas econômicas dos Estados subdesenvolvidos. ${ }^{19}$

17 MELLO, Celso de Albuquerque. Op. cit., p. 123.

18 A Carta de Lei de 25 de março de 1824, observada como "Constituição do Império" determinava, em seu art. $1^{\circ}$, que "O Império do Brasil é a associação política de todos os cidadãos brasileiros. Eles formam uma nação livre e independente que não admite com qualquer outra laço algum de uniāo ou federação, que se oponha à sua independência."

A Constituição de 1891 cuidou da soberania nacional no art. 15, afirmando serem seus órgãos os poderes legislativo, executivo e judiciário. A expressão teve, então, o sentido de poder e não mais de independência no sentido de que se valera o constituinte do Império.

A Constituição de 1934 manteve, em seu art. $3^{\circ}$, aquela expressão com o mesmo significado utilizado naquela primeira da República.

A Carta de 1937 estabeleceu, em seu art. $1^{\circ}$, que "O poder político emana do povo e é exercido em nome dele e no interesse do seu bem-estar, da sua honra, da sua independência e da sua prosperidade".

A Constituição de 1946, a Carta de 1967 e a Emenda Constitucional n. 1, de 1969, não faziam expressa referência à independência ou à soberania, mas cuidavam das competências da Uniāo para assegurar a integridade do território nacional e ao trânsito de estrangeiros ou de forças estrangeiras no país, donde se extraía a adoção inequívoca, obviamente, daquele princípio.

19 Cf. SILVA. José Afonso da. Curso de direito constitucional positivo. Sāo Paulo: Malheiros, 1998, p. 724. 
O fortalecimento da soberania popular é que se põe, na presente quadra histórica, como importante. Soberano é o cidadão e não o Estado. Atente-se a que a cidadania, por sua vez, é cada vez mais supranacional. O direito de participar do poder político não mais se restringe ao território de um Estado, estendendo-se principalmente porque ele se exerce para assegurar a dignidade da pessoa humana - princípio essencial de qualquer ordenamento - e onde esta tiver sido atingida há que haver um cidadão disposto a colaborar com o ameaçado ou lesado em seu direito para a pronta defesa, independente da nacionalidade.

Ademais, considerando-se que a democracia é tida como direito fundamental da terceira onda (ou de terceira geração como querem alguns autores), a soberania do povo cumpre a tarefa de assegurar que a sua participação não lhe seja negada, menos ainda afastada para se substituir pelos eventuais governantes.

Neste sentido, a soberania popular pode representar uma maior legitimidade das normas jurídicas que passem a integrar e a incidir sobre o povo de um Estado, mesmo quando formulado internacionalmente, porque esta elaboração contaria (e, quem sabe, contará brevemente) mais com a participação dos cidadãos, o que, até agora, ainda é muito frágil.

13 - $\mathrm{Na}$ interconexão do direito interno com o direito internacional é de se atentar a que a limitação das competências do Estado pela atribuição conferida aos órgãos que produzem as normas supranacionais constitui, iniludivelmente, uma limitação à própria soberania do Estado, se pensada essa em sua concepção mais vinculada à idéia de capacidade suprema de produzir, por si e internamente, uma ordem jurídica. Se se põe que o constitucionalismo contemporâneo privilegia a produção heterógena de normas para possibilitar uma maior composição de interesses dos povos integrados ou reunidos em comunidade com a participação popular soberana e efetiva, parece indubitável que se pode considerar a manutenção daquele conceito e até mesmo o seu fortalecimento.

A matéria dos direitos humanos, que dominam o cenário jurídico nas últimas décadas, vem comprovar que a soberania estatal não se sobrepõe ao direito que resguarde o homem em sua condição universal. O cuidado daquele tema constitui, irretorquivelmente, uma superação da soberania estatal absoluta e intangível ao questionamento do resto do mundo.

É de se observar, porém, que a soberania é repensada para se impor mais fortemente não em sua verticalidade, mas em sua projeção horizontal e não em relação ao aparato burocrático dos poderes que compõem os quadros de ação do Estado, mas em respeito à atuação cidadã permanente, intransferível e decisiva dos povos interessados.

Neste caso, a soberania cumpre também uma função de por a claro as desigualações que marcam as identidades dos povos, que devem ser respeitadas, vez que não se pretende aceitar a uniformização totalitária dos grupos sociais ou a unificação das culturas que acarretam o esfacelamento das individualidades em único proveito de interesses de mercados sem qualquer compromisso com as reais necessidades dos diferentes conjuntos, garantindo-se pela participação popular que se propiciem as condições de aperfeiçoamento respeitoso das desigualdades para a identificação e o respeito às peculiaridades culturais e sociais. A comunhão de Estados ou a integração 
de Estados não pode significar a supressão. a eliminação ou a simples extinção das diferenças dos povos e de suas culturas. pois elas devem se somar para acrescentar e se constituir objeto da união. Só há união quando há mais de um. Não há uma cultura ou opção política de um povo que seja a verdade absoluta ou que seja boa para todos. A hegemonia é nefasta e negadora da liberdade humana que encarece a diferença que individualiza, torna o ser um indivíduo único, diferente dos demais. Para haver a aproximação dos povos há que se partir do respeito as suas diversidades. É, aliás, a diferença que nos caracteriza. quer dizer, dota-nos de singularidade para nos superarmos. A igualdade que se busca não suprime as singularidades, apenas se restringe a impedir que as diferenças decorrentes de preconceitos nos inferiorize e marginalize. Não se pretende um mundo de seres idênticos, despersonalizados. Antes, quer-se um mundo de pessoas, que se qualificam pela sua condição especial e única. O pluralismo político vale não apenas como fundamento da democracia interna dos Estados, mas também internacional. Portanto, não se há cogitar de anular as identidades nacionais, pois então não há integração ou comunhão, mas colonização ou dominação pura e simples.

Afinal, como dizem os indianos, a universalidade repousa na humanidade que se individualiza, se marca e se faz irmão. Por isso "cantes a tua aldeia se queres ser universal". Há de se manter a aldeia para fazer surgir o canto...

\section{IV - A Constituição da República Brasileira e o Mercosul}

"Celso Furtado ... enfatiza ser nossa tarefa nada menos do que 'mudar o curso da civilização, deslocar o sell eixo da lógica dos meios a serviço da acumulação num curto horizonte de tempo, para uma lógica dos fins em função do bem estar social, do exercício da liberdade e da cooperação entre os povos'. Enfrentar a crise civilizatória exige um grande grau de cooperação em nível internacional, muito superior a tudo o que se fez até hoje".

- Mais além do mercado, mais além do Estado Armando de Melo Lisboa

14 - O Mercosul busca realizar, no âmbito do Cone Sul, a integração, inicialmente econômica dos Estados-partes, no fluxo do que se constrói ou se intenta produzir o direito da integração. Releve-se: é o direito da integração, pois não se quer que se tenha por cá o direito da "entregação". Quer dizer, no âmbito de uma globalização econômica sobre a qual se põem questões de monta para a sobrevivência independente de cada povo a integração vem para ajustar sociedades que se podem reunir para aperfeiçoar as suas instituições e se solidarizarem nas decisões em benefício de todos. Independência não significa isolacionismo, fechamento ou desconhecimento da realidade e da coordenação com as políticas internacionais. Mas integração também não pode significar dependência, menos ainda aquela que faz que um povo entregue a outro Estado os seus bens, os seus recursos, a sua história, o seu futuro. Integração faz-se com soma para melhor distribuição com todos e não com a subtração para maior lucratividade de alguns. 
A globalização que se oferece como fatalidade ${ }^{20}$ do atual momento histórico é a econômica e não é um processo que titularize os Estados na condição de principais protagonistas. Antes. ela vem como uma condição de realização de capitais e interesses particulares valendo-se dos agrupamentos humanos como manadas de consumidores que oferecem o cheiro do lucro a ser revertido em benefício dos empresários. Não é um processo no qual atue predominantemente o Estado, pelo que o seu ordenamento não submete tal atividade. Em verdade este processo de globalização econômica não dispõe de leis, pois as denominadas "leis do mercado" são verdadeira e exclusivamente o domínio da força. ${ }^{21}$ No curso desta mercantilização das relações internacionais, há crescente presença dos Estados economicamente fortes sobre os outros, que aqueles pretendem usar segundo as suas conveniências financeiras, num neocolonialismo que não renega a história de exploração de alguns países por outros e para o que se pretende uma hegemonia contrária aos ideais de libertação e aos princípios da liberdade e da igualdade. Segundo Alain Tourraine, "o que hoje chamamos de globalização, há cerca de um século atrás era chamado de imperialismo. Este conduziu a rupturas sociais e políticas que disseminaram governos despóticos e, mais cedo ou mais tarde, paralisaram as economias submetidas ao poder totalitário". ${ }^{22} \mathrm{O}$ autoritarismo econômico internacional ronda as relações entre os Estados. A arquitetura política globalizante neoliberal gera a desigualdade. Esta, como se sabe, é produzida, não é gerada do nada. E a desigualação econômica vem gerando legiões de desempregados e de não trabalhadores, excluídos do processo social e político porque não são agentes da lógica econômica de se ter direitos apenas se se puder fazer por merecê-los. Aquele que não tiver oportunidade de "fazer" (o que se tem pelo trabalho) não se vê incluído no processo sócio-econômico.

A esta lógica de mercado sem leis conjuga-se o neoliberalismo de perfil individualista sem o resguardo das individualidades e a competitividade com a paralela extinção de empregos e de trabalhos sob os quais se afirmava a organização social e, em grande parte, também a organização econômica. ${ }^{23}$

A mundialização dos direitos humanos e a universalização das garantias fundamentais do homem são a tônica mais realçada e própria para a realização da dualidade

20 Quanto a ser considerado uma "fatalidade" do momento atual é de se anotar que a aids também é uma fatalidade do momento atual e nem por isso há que se deixar de lutar para exterminá-la; 0 câncer também é uma fatalidade e continua a se buscar a sua cura. $O$ que chega ao homem como fatalidade nem sempre é insuperável, menos ainda quando é fator externo e criado por ele mesmo como se tem com a arquitetura globalizante e neoliberal da macroeconomia.

21 Segundo George Soros, milionário que fez a sua fortuna exatamente com as "leis do mercado", "atualmente as finanças internacionais não obedecem a nenhuma lei. Quando uma atividade está fora do alcance da lei, o que predomina é a força - e o estado de coisas em que a força predomina é chamado de barbárie". In Revista Veja, n. 1442, p. 10.

22 TOURRAINE, Alain. Riscos do pensamento único. In Jornal Folha de São Paulo, 18.02.96, p. 5-7. 23 'A gravíssima crise que hoje vivemos é uma crise da possibilidade do 'desenvolvimento' latino-americano, do sonho da modernização de nossas terras. ... abre-se um vácuo quando se constata: seja os limites do Estado na condução do processo social, seja a irrevogabilidade dum mercado transnacional devorador dos nossos recursos humanos e naturais, seja a inadequaçāo do projeto neoliberal necessariamente excludente da maioria da população, seja quando se questiona a possibilidade da justiça e dum amanhā fraterno para nossos povos" (LISBOA. Armando de Melo. loc. cit., p. 134). 
internacional que se põe e segundo a qual os Estados se reúnem para se fortalecerem e se prestarem à solução de problemas comuns com a soma dos seus esforços, recursos e comportamentos, para o que, paralela e contrariamente, necessitam abrir mão do sentido absolutista e exclusivista que o conceito antigo de soberania abrigava. Mas sem o associacionismo internacional dos Estados, especialmente dos mais fracos economicamente, ter-se-á o retorno ao imperialismo em sua feição mais perversa.

A integração das nações do Cone Sul, as quais precisam ainda realizar, primariamente, para todos os seus cidadãos os direitos fundamentais - inclusive e ainda os denominados de primeira onda ou de primeira geração, como sejam, o direito à vida, o direito à liberdade, o direito à igualdade, dentre outros -, deve apontar para alternativas da estabilização democrática segundo as condições sócio-culturais e políticas a fim de obter, com segurança e sem retrocessos, a estabilização econômica inclusive no plano das parcerias internacionais.

A integração referida constitucionalmente pelas normas fundamentais da República Federativa do Brasil (art. $4^{\mathfrak{Q}}$ e seu parágrafo único) busca a preservação das identidades nacionais que se devem somar para multiplicar e dividir bens e não para aumentar as desigualdades, menos ainda pagar com a pobreza maior ainda de seus cidadãos o lucro particular de empresas descomprometidas com o homem sul-americano. Por isso não se cogita da integração exclusivamente econômica, conquanto seja certo que o Mercosul é, hoje e ainda, fundamentalmente, um processo essencialmente econômico.

O modelo de globalização econômica neoliberal pode conduzir a uma mais crescente condição de miserabilidade de populações sul-americanas inteiras, que não dispõem de qualificação para a competição internacional com as poderosas economias industrializadas e dotadas da melhor e mais avançada tecnologia. A ordem social proposta até mesmo nos sistemas constitucionais dos Estados subdesenvolvidos não tem conseguido, ainda, romper a desigualação forjada pelo modelo econômico descomprometido com os homens.

Os fantasmas da pobreza indigna trazidos pela lex mercatoria ${ }^{24}$ sem fulcro social e sem finalidades humanas andam pela casa e já não podem ser desconhecidos. Tropeçam-se em mãos estendidas à cata de um taco de pão. E, como bem assinala o Pe. Inácio Neutzling, "os pobres são os juízes da vida política e econômica de uma nação. Portanto, a situação dos pobres em nossos países é o critério para medir a justiça, a bondade, enfim, a moralidade da integração que o Tratado do Mercosul pretende implementar". ${ }^{25}$

A imposição, que vem de fora, de modelos de Direito minimamente materializados, de desconstitucionalização e de desregulamentação das matérias que são imprescindíveis para a garantia dos direitos fundamentais do povo sul-americano, não pode ser aceito.

24 Já há quem alegue que a lex mercatoria é um novo direito (Cf. Patrícia Luíza Kegel. Internacionalizaçâo do Estado e Sistemas jurídicos nacionais. In Advogado: desafios e perspectivas no contexto das relaçōes internacionais. Brasnilia: OAB, 1998, ps. 73 e 75.

25 NEUTZLING, Inácio. loc. cit., p. 125. 
Não é possível, admissível ou aceitável que o ciclo civilização/ desenvolvimento/ modernização se faça ao custo da exclusão social e da marginalização política cada vez maior de povos e de grupos sociais. O homem não é a taxa de lucro de empresa.

Não se deseja negar o crescimento econômico, menos ainda isolar-se o Estado sul-americano do processo econômico internacionalmente dinamizado. O que se pretende é que este modelo seja projetado e realizado em benefício de todos os homens e não para o proveito de alguns à custa da maioria dos mais e mais empobrecidos. O mercado, que é necessário, haverá que ser voltado para o atingimento das finalidades sociais dos homens. Não são os homens que se devem organizar para atender fins do mercado. Por isso a democracia haverá que ser, rigorosamente, observada como base imprescindível para a integração, pois somente ela pode assegurar uma ordem social justa e solidária. A ética democrática não pode ser desconsiderada no processo de integração. É ela que pode afirmar o acatamento rigoroso dos princípios constitucionais democráticos dos diversos Estados integrados, garantindo-se, então, a o pluralismo cultural, social e econômico e permitindo-se a elevação dos membros destas sociedades à condição de cidadãos sul-americanos, iguais em direitos aos demais cidadãos do mundo. A assimetria comercial, social, cultural e histórica dos povos e Estados latino-americanos não pode ser desconhecida ou renegada para se copiar, independente do chão latino-americano, modelos que se forjam em laboratórios outros inteiramente defasados da realidade de cá.

É mister evitarem-se os projetos que conduzam ao dumping social de inegáveis consequiências sociais malignas para os Estados do Cone Sul. Somente com o respeito e o engajamento às peculiaridades histórico-culturais das sociedades latino-americanas é que se poderá evitar aquele resultado nefasto aos cidadãos.

15 - Há de se atentar, então, à primazia absoluta dos princípios das Constituições dos Estados latino-americanos que resguardem, garantam e realizem a democracia das sociedades que se dão à integração no Cone Sul.

A Constituição Brasileira não determina a busca da integração sem a imprescindível observância dos princípios que informam e conformam o Estado brasileiro, na base do qual se põe superior e incontestavelmente a dignidade da pessoa humana, bem como o da soberania popular, o da cidadania e o do pluralismo político, dentre outros (art. $\left.1^{0}\right)$.

Ao contrário dos Estados europeus que tiveram como fundamento preliminar da formação de sua comunidade a necessidade de se preservar a democracia para se assegurar a continuidade dos processos sócio-econômicos, econômicos e políticos de progresso e o respeito às nacionalidades com o fortalecimento das pessoas políticas, os Estados latino-americanos, melancolicamente, têm como desafio a construção de uma democracia social e política estável e permanente, que não se pode encontrar em sua história.

Novas cópias de modelos estrangeiros, inclusive políticos; a submissão a ordens econômicas, menos ainda incoerentes com os reclamos sócio-culturais do povo; a aniquilação das peculiaridades e riquezas culturais dos povos latino-americanos para a absorção de abúlicas fórmulas macdonalizadas de viver sob o jugo imperialista de uma mídia cuja pátria é o lucro financeiro não são sendas próprias a se percorrerem. 
Nem a Constituição da República Federativa do Brasil permite novas e subliminares formas de dependência a ordens internacionais ou a entrega do país a interesses que não os prioritariamente nacionais.

Neste sentido é que somente se pode considerar legítimo o processo de integração latino-americano para a criação da Pátria Grande subsumido aos paradigmas democráticos e voltados ao cumprimento de todos os fatores determinantes da reunião criativa e criadora da entidade de direito internacional, como se considerou protocolarmente o Mercosul (art. 34, do Protocolo de Ouro Preto). O direito da integração, forjado a partir dos atos, acordos e tratados afirmados pelos Estados-partes do Mercosul, não poderá desconsiderar qualquer daqueles princípios democráticos, pois sem a sua observância não se poderá ter a base que alicerça uma integração firmada no Direito.

Ademais, tendo-se como fundamento principiológico da integração a democracia buscada no princípio da soberania popular, é patente que haverá de se preverem mecanismos e instrumentos assseguradores da participação efetiva dos cidadãos no processo, sem o que se terá dificuldades para possibilitar a legitimidade política das decisões tomadas no âmbito dos diferentes Estados e, de par com essa questão, a eficácia jurídica destas decisões na esfera de competências de cada qual.

Mais ainda, há de se anotar que a adoção de políticas públicas a serem concretizadas em relação às sociedades que participam do processo integracionista depende do atendimento de um sistema de controle democrático da esfera pública, pois não há democracia sem a limitação do exercício das competências pelos agentes estatais, menos ainda sem um eficiente sistema de aferição da juridicidade deste desempenho. Logo, é imperioso que se tenha a institucionalização dos mecanismos de participação direta ou indireta, porém democrática e com representação específica, do cidadão na gestão da coisa pública regionalmente integrada, tanto para a adoção de providências e decisões, quanto para o controle de sua execução.

Há excessiva burocratização na ustitucionalização do Mercosul, distanciandose muito dos cidadãos. Estado como a República brasileira, que já tem, internamente, tantas e tão grandes diferenças, não chegará a suprir a exigência democrática se não adotar uma política de divulgação e de aproximação de todos os segmentos sociais e entidades federadas com o processo de integração, hoje muito restrito ao sul e sudeste do país.

Somente se terá o despertar da sensibilidade social do cidadão latino americano quando se adotar, efetivamente, uma agenda social e cultural como ponto fundamental do processo. Tal agenda é necessária por causa dos princípios fundamentais da República Federativa Democrática do Brasil e dos direitos humanos que hoje dominam o direito internacional. Sem o homem sul americano não há América do Sul. Sem povo não se faz Estado Democrático. Sem cultura popular não se promove integração por falta de objeto a ser reunido.

O desemprego que vem assolando multidões, se não é um caso isolado ou único da América do Sul, deve se constituir em preocupação específica do Mercosul, onde os desníveis têm se acentuado de maneira disparada nesta década de noventa. $O$ ingresso de um contingente de um milhão e quinhentos mil trabalhadores ingressando, apenas no Brasil, no mercado de trabalho anualmente e sem encontrar geração 
correspondente de empregos pode desaguar numa marginalidade sem precedentes na história do Brasil.

Os desniveis entre as condições dos trabalhadores dos Estados-partes do Mercosul e a desigualdade das formas e condições de produção de bens e serviços (Estado como o Paraguai é mais agrícola, enquanto o setor de serviços tem um desenvolvimento prioritário, por exemplo, no Uruguai) podem criar fossos enormes a separar e a estancar as realidades sócio-econômicas se não forem pensadas em conjunto e a tempo de se desenvolverem procedimentos que conduzam à superação das diferenças de base sócio-econômica.

A integração latino-americana determinada pela Constituição brasileira de 1988 não estanca apenas um fator de reunião e coordenação - o econômico - como se tem reforçado até aqui. Urge se ampliem os fatores de integração para o cumprimento daquela meta e para o completamento do processo.

\section{Conclusão}

"Os outros latino-americanos são como nós mesmos, povos novos, em fazimento. Tarefa infinitamente mais complexa, porque uma coisa é reproduzir no além-mar o mundo insosso europeu, outra é o drama de refundir altas civilizações, muito diferente, é o nosso, de reinventar o humano, criando um novo gênero de gentes, diferentes de quantas haja".

- O povo brasileiro -

Darcy Ribeiro

A integração latino-americana que o Mercosul, conquanto havida no fluxo de uma globalização econômica desapegada de ideais humanitários e universalmente comprometidos com os cidadãos, enseja e enceta o surgimento de um momento inteiramente novo na América Latina.

Esta integração, que a Constituição brasileira determina seja buscada pela República e que se põe no panorama internacional como uma contingência do associacionismo dos povos e dos Estados, deverá se desenvolver segundo os princípios democráticos da ética, da liberdade, da solidariedade e da justiça social para ser válida. Se não houver o fundamento do processo nos princípios universais asseguradores da dignidade da pessoa humana, qualquer forma de atuação política das entidades estatais estará fadada ao insucesso social e ao fracasso jurídico e político.

O Mercosul é uma realidade que tem um largo caminho a percorrer. Não se há de aceitar desvios que venham como propostas de povos que não conhecem as contingências sócio-políticas e econômicas da região integrada, nem se há de fechar ao que venha de novo e de propício a um aperfeiçoamento das instituições sociais.

A ética social justa do processo da integração passa pela democratização das instituições e dos fins do Mercosul. Há de se convocar o cidadão latino-americano a participar politicamente das tomadas de decisões, de maneira eficiente e permanente, mediante a prévia divulgação dos temas, programas, projetos e deliberações 
a serem discutidas e decididas, a fim de que se assegure a legitimidade do processo que garante, em grande parte, a efetividade social das decisões.

Também não se pode desconhecer que os direitos humanos e os direitos sociais têm que ter prioridade absoluta no processo da integração, considerando-se uns e outros na contingência latino-americana e não como se passa a sua garantia em outros Estados.

Afinal, há quinhentos anos de história para se ganhar e que a integração poderá ajudar a converter numa nova América. Não é sem tempo que se construirá a Pátria Grande segundo os ideais de solidariedade e justiça que animaram os americanos dos últimos três séculos. Para tanto, há de se pensar a integração lendo a nossa história com os nossos próprios olhos e pensá-la com os nossos conhecimentos de chão. Somos nós mesmos a nossa cartilha e o nosso projeto de uma vida que atenda aos destinos traçados para uma realidade que não tem retrato nos outros continentes. Somos, com as nossas agruras históricas e sociais presentes, o nosso próprio fardo, mas somos também a nossa maior esperança. Se aquele pesa mais na reunião de Estados, esta se multiplica na integração dos homens.

\section{Bibliografia}

ALMEIDA, Antônio José et alii. Mercosul. Petrópolis: Vozes, 1997.

BAPTISTA, Luiz Olavo. O Mercosul suas instituições e ordenamento juridico. São Paulo: LTr, 1998.

BASSO, Maristela. Mercosul. Porto Alegre: Livraria do Advogado Editora, 1997.

BONAVIDES, Paulo. Curso de Direito Constitucional. São Paulo: Malheiros, 1998.

Ciência Política. São Paulo: Malheiros, 1993.

BOSON, Gerson de Britto Mello. Constitucionalização do Direito Internacional. Belo Horizonte: Del Rey, 1996.

CHIARELLI, Carlos Alberto Gomes e CHIARELLI, Matteo Rota. Integração: direito e dever. São Paulo: LTr, 1992.

BURDEAU, Georges; HAMON, Francis; TROPER, Michel. Droit Constitutionnel. Paris: LGDJ, 1993.

CANOTILHO, J.J. Gomes. Direito Constitucional e Teoria da Constituição. Coimbra: Almedina, 1998.

CARTER, Lief H. Derecho constitucional contemporaneo. Buenos Aires: Abeledo-Perrot, 1985.

CASELLA, Paulo Borba. Integração Jurídica Interamericana. São Paulo: LTr, 1998.

Mercosul, exigências e perspectivas. São Paulo: LTr, 1996.

DOUTRIAUX,Y ves; LEQUESNE, Christian. Les institutions de l'Union européenne. Paris: La documentation française, 1995.

DROMI, Roberto. Codigo del Mercosur. Buenos Aires: Ediciones Ciudad Argentina, 1996. 
GARCIA, Armando Alvares Garcia. Conflito entre normas do Mercosul e Direito Interno. Sāo Paulo: LTr, 1997.

GREWE, Constance \& FABRI, Hélène Ruiz . Droits constitucionnels européens. Paris: Presses Universitaires de France, 1995.

HESSE, Konrad. Escritos de derecho constitucional. Madrid: Centro de Estudios Constitucionales, 1983.

LEAL, Rosemiro Pereira. Soberania e mercado mundial. São Paulo: Editora de Direito, s/d.

LOBO, Maria Teresa Cárcomo. Ordenamento juridico comunitário. Belo Horizonte: Del Rey, 1996.

MELLO, Celso Albuquerque. Direito Internacional da Integração. Rio de Janeiro: Renovar, 1996.

Direito Constitucional Internacional. Rio de Janeiro: Renovar, 1994.

SILVA, José A fonso. Curso de direito constitucional positivo. São Paulo: Malheiros, 1998.

SMEND, Rudolf. Constitucion y Derecho Constitucional. Madrid: Centro de Estudios Constitucionales, 1985.

SOARES, Esther Bueno. Mercosul. Belo Horizonte: Del Rey, 1997.

VENTURA, Doris et alii. Porto Alegre: Livraria do Advogado Editora, 1997. 


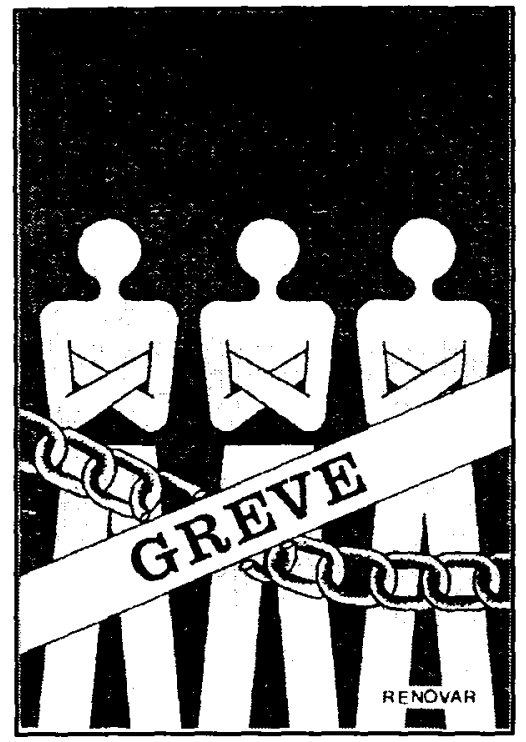

Ref. 0005

Brochura

130 págs.

Form. 14x21

1986

\section{GREVE}

José de Segadas Vianna

Livro que objetiva facultar aos estudiosos do Direito Coletivo do Trabalho, e aos dirigentes sindicais, um conhecimento e uma visāo geral desse problema que preocupa toda a coletividade, os trabalhadores, os empresários e o governo: a greve. Setores empresariais procuram aproveitar-se dos movimentos grevistas para obter reajustamentos de preços e repassar aumentos salariais aos consumidores. Em vez de reduzirem seus lucros, debatem a baixa de juros, subsídio para certos empreendimentos, ameaça de demissões em massa, querendo enfraquecer o sindicalismo e reduzir atribuições da Justiça do Trabalho. 